\title{
18. BASAL FERRUGINOUS SEDIMENTS CORED DURING LEG 16, DEEP SEA DRILLING PROJECT
}

\author{
David S. Cronan, Department of Geology, University of Ottawa, Ottawa, Canada
}

\begin{abstract}
Ferruginous sediments similar to those found on previous Pacific legs of the Deep Sea Drilling Project occur just above basement at four of the Leg 16 sites. These sediments are enriched in $\mathrm{Mn}$ as well as Fe, and some contain high concentrations of $\mathrm{Zn}, \mathrm{Ni}, \mathrm{Co}, \mathrm{Cu}$, and $\mathrm{Pb}$. The sediments are chemically similar to those found on the East Pacific Rise at the present time. They were probably formed by hydrothermal activity when the basement was at the rise crest and have moved to their present positions as a result of sea floor spreading.
\end{abstract}

\section{INTRODUCTION}

One of the aims of drilling on the west flank of the East Pacific Rise during Leg 16 of the Deep Sea Drilling Project was to search for the basal iron-rich sediments which have been reported on previous Pacific legs of the project (von der Borch and Rex, 1970; von der Borch et al., 1971; Cook, 1971). In this we were successful, finding ferruginous sediments at the base of three of the holes and slightly ferruginous sediments at the base of one other. The purpose of this report is to present a brief description and some chemical analyses of these deposits and a preliminary discussion of their origin.

Aluminum-poor ferromanganoan sediments have been described from various locations in the ocean in recent years, but principally from active mid-oceanic ridge crests. Boström and Peterson (1966) first drew attention to the presence of metal-rich sediments in areas of high heat flow at the crest of the East Pacific Rise and considered that they were of hydrothermal origin. These sediments contain abundant, brown, X-ray-amorphous metal precipitates and show an enrichment of $\mathrm{Fe}, \mathrm{Mn}, \mathrm{Cu}, \mathrm{Cr}, \mathrm{Ni}$, and $\mathrm{Pb}$ over the normal values for pelagic sediments. More recent studies by Boström et al. (1969) and Boström and Fisher (1971) have extended these conclusions to active ridge areas in the Atlantic and Indian oceans. Similar iron-rich deposits related to submarine volcanic activity have been reported by Zelenov (1964), who actually observed their precipitation, and Bonatti and Joensuu (1966). The possibility that ferromanganoan sediments might occur underneath a blanket of more recent sediments away from active ridge crests was considered likely by Boström and Peterson (1969) on the basis of the hypothesis of sea floor spreading (Vine and Matthews, 1963) and was confirmed by Peterson, Edgar et al. (1970), who found iron-rich sediment just above igneous rock in the Atlantic Ocean on Leg 2 of the Deep Sea Drilling Project. Subsequent legs of the project have found such sediments in the Pacific Ocean, particularly in the eastern Pacific, and it seems likely that buried ferruginous sediments exist over large areas of the ocean floor.

\section{SEDIMENT DESCRIPTIONS}

Except in the very pure biogenic oozes, grains and aggregates of iron oxides were found throughout most of the sediments cored during Leg 16, generally in small concentrations. Near the base of DSDP 159, 160, 161, and 162 , however, they constitute a sizeable proportion of the sediment. In each of these cases the iron oxides are admixed to a greater or lesser extent with biogenous materials, usually calcareous nannofossils, and are most abundant immediately overlying the basalt at the base of the sections. The oxide grains themselves are characteristically spherical to subspherical in shape and range from a few microns to a few tens of microns in diameter. They vary from opaque to translucent and are generally reddish to yellow brown in color. The general properties and stratigraphic relations of these deposits have been described in their respective site chapters earlier in this volume, but some comments are necessary here.

\section{DSDP 159}

The lower part of DSDP 159 consists predominantly of nannofossil chalk ooze which varies in color from moderate yellow brown and grayish orange at 70 to 80 meters below the surface to a dark moderate brown below 100 meters. The sediments are early Miocene in age. Iron oxide grains and aggregates become more abundant with increasing depth in this interval and reach their maximum concentration below 100 meters. The lowermost sediment core in the section (107-108 m) consists of slurried carbonate, clay, and basalt chips and may, in part, represent a thin basal clay unit which has been disturbed by the drilling process. The underlying material at 108 meters is basalt.

\section{DSDP 160}

At DSDP 160, the sediments between 63 and 108 meters consist of light-colored Oligocene nannofossil chalk ooze containing very little ferruginous material. However, as at Site 159, the lowermost sediment core contains fragments of the overlying calcareous beds mixed with basalt 
cuttings in a muddy matrix. Much of the mud is slurried, but at 108.4 meters below the surface there is a small patch of dark brown clayey sediment containing abundant yellow brown ferruginous aggregates. This, like the basal sediment at DSDP 159, may represent part of a clay unit immediately overlying basalt.

\section{DSDP 161}

The lowermost sediment unit at DSDP 161, between 200 and 244 meters below the surface, consists of indurated Eocene radiolarian ooze, largely free of calcareous material. Ferruginous grains are common throughout this dark yellowish brown sediment but are rare in the overlying, very pale, almost iron-free nannofossil chalk ooze.

\section{DSDP 162}

The basal sediments at DSDP 162 are more variable than are those at the other sites where ferruginous deposits are common. Between 144 meters and 153 meters the sediment is zeolitic brown clay grading downward into foraminiferal nannofossil marls and chalks. These deposits, of Eocene age, contain scattered iron oxide grains throughout, together with feldspars and volcanic glass in the coarse fraction.

\section{COMPOSITION}

Thirty-four sediment samples were selected from various depths at DSDP 159,160,161,162, and 163 for the determination of the metals $\mathrm{Fe}, \mathrm{Mn}, \mathrm{Ni}, \mathrm{Co}, \mathrm{Cu}, \mathrm{Pb}$, and $\mathrm{Zn}$. The results are presented on a calcium-carbonate-free basis in Table 1.

Prior to analysis, the samples were ground to a fine powder and heated to $105^{\circ} \mathrm{C}$ to remove moisture. Iron was determined by precipitation of the hydroxide, redissolution, reduction, and titration with 0.1 Normal $\mathrm{K}_{2} \mathrm{Cr}_{2}$ $\mathrm{O}_{7}$ standard solution. $\mathrm{Mn}, \mathrm{Ni}, \mathrm{Co}, \mathrm{Cu}, \mathrm{Pb}$, and $\mathrm{Zn}$ were determined by atomic absorption spectrophotometry on a Techtron Mk 4 instrument after dissolution in a 3:1 mixture of concentrated nitric and hydrochloric acids.

The data show that the basal sediments at DSDP 159 and 162 are markedly more ferruginous than those higher in the sediment column, whereas there is only a slight enrichment in iron at the base of DSDP 160. There is an apparent lack of iron enrichment at the base of DSDP $161 \mathrm{~A}$, even though this sediment was seen under the microscope to contain abundant ferruginous material. The low iron values in this core probably reflect its dilution by opaline silica. Recalculation of the analyses on a biogenous-silica-free basis (Cronan et al., 1972) gives an approximate value of 13 to 14 per cent iron in these sediments. There seems to be no iron enrichment at DSDP 163.

Elements other than iron are also enriched in some of the basal sediments (Table 1). In the lower portions of DSDP 159,160 , and 162, and, on a biogenous-silica-free basis, at DSDP 161A, manganese is concentrated severalfold over its concentrations higher in the sections. Zinc, nickel, cobalt, copper, and lead are also enriched in many of the ferruginous sediments.
Examination of the composition of some sediments higher in the cores (Table 1) shows that there is enrichment of iron at some horizons here also. In Core 6 of DSDP 159, Core 3 of DSDP 160, and Core 12 of DSDP 162 , for example, the iron and some of the minor element concentrations are higher rather than deeper in the holes, indicating that deposition of excess ferruginous material is not restricted to basal portions of the sections.

Comparison of the average composition of the eleven samples of ferruginous basal sediment analyzed in this work with the average composition of seven ferruginous sediments described by Boström and Peterson (1969) from areas of high heat flow on the East Pacific Rise shows many similarities (Table 1). The iron contents of the two groups of samples are remarkably close, and good agreement is also found between the two sets of minor element values. In addition, each of the two groups of sediments is markedly enriched relative to the average composition of Pacific surface pelagic clays (Cronan, 1969) in all the elements sought other than $\mathrm{Co}$, and $\mathrm{Pb}$, the data for $\mathrm{Pb}$ being incomplete. However, the significance of the latter comparison is questionable inasmuch as Bonatti et al. (1971) have suggested that average abundances of elements in surface pelagic sediments may not necessarily reflect their overall abundance in pelagic sediments as a whole. These authors speculate that a zone of reduced sediments may exist below the oxidized sediments in pelagic areas, and, if so, $\mathrm{Cr}, \mathrm{V}$, and $\mathrm{U}$ are likely to be enriched in the former and $\mathrm{Mn}, \mathrm{Ni}, \mathrm{Co}, \mathrm{Pb}$, and $\mathrm{La}$ in the latter. However, no reduced sediments were encountered at DSDP $159,160,161$, or 162 , each section being well oxidized down to the underlying basalt. It is likely, therefore, that the present sediments are more directly comparable with oxidized surface sediments than with buried reduced sediments, and thus the comparison with the data of Cronan (1969) is probably valid. If this is so, it is evident that these sediments contain large excesses of several elements normally present in pelagic sediments in much lower concentrations.

\section{DISCUSSION}

The basal ferruginous sediments described in this work are, in general, similar to those described previously from the Pacific Ocean (von der Borch and Rex, 1970; von der Borch et al., 1971) in that they consist predominantly of amorphous iron oxide precipitates admixed with variable proportions of detrital and biogenic materials. At DSDP 159 and 162 the ferruginous sediments grade upward into more normal pelagic deposits as they do at DSDP 37,38 , and 39 (von der Borch and Rex, 1970). At DSDP 160 and 161 , on the other hand, they are sharply overlain by calcareous oozes as at DSDP 74 and 75 (von der Borch et al., 1971). The latter authors explain the abrupt change in lithology at DSDP 74 in terms of a 10 my hiatus at the top of the iron oxide unit and consider that a similar hiatus might also occur at DSDP 75. They propose that, during the period represented by the hiatuses, the sea floor moved away from the areas of iron oxide precipitation as a result of sea floor spreading. Small hiatuses could possibly account for the sharp boundaries between the ferruginous 
TABLE 1

Composition of Sediments Collected During DSDP Leg 16

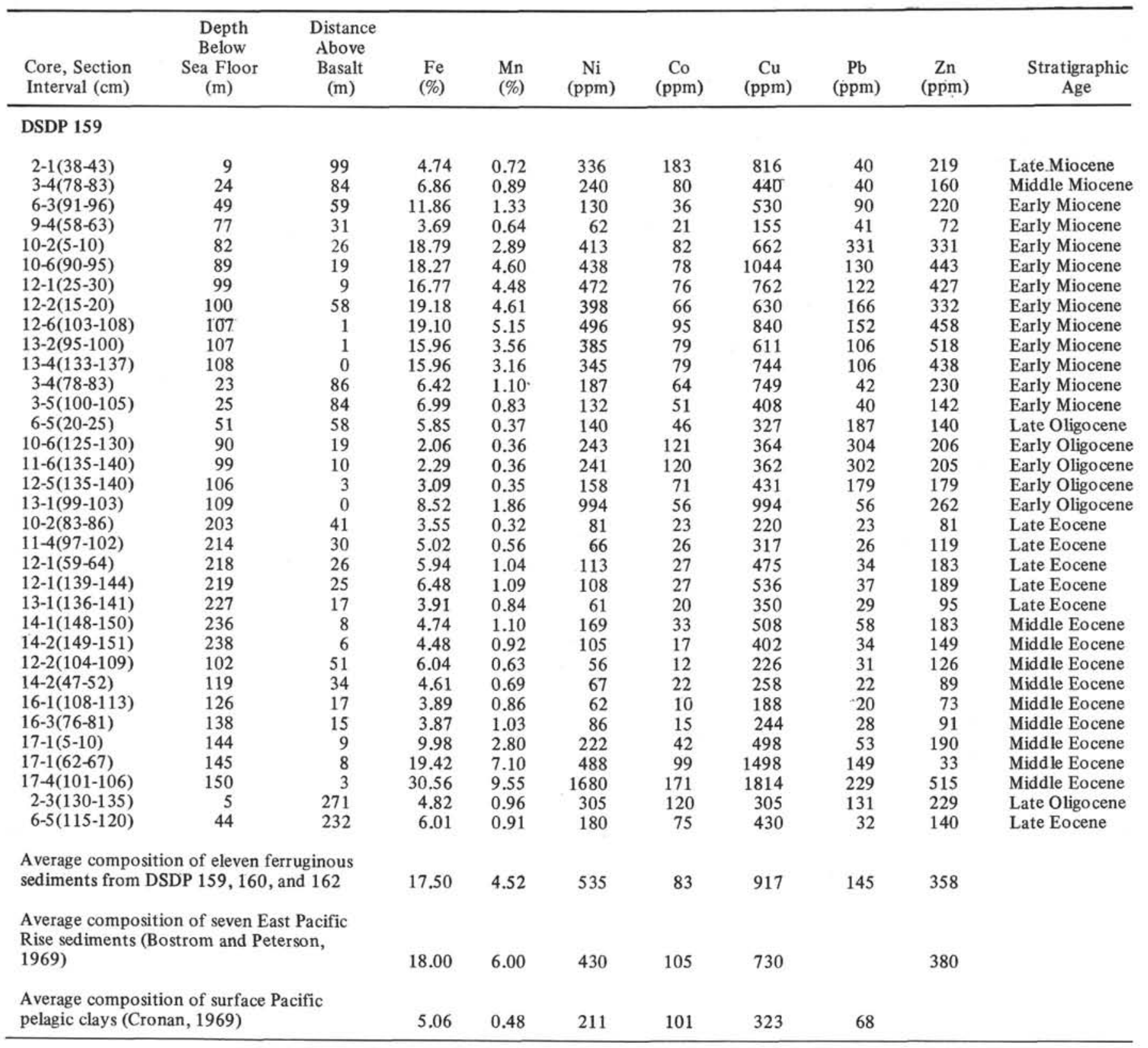

sediments and the overlying calcareous oozes at DSDP 160 and 161 , although there is no paleontological evidence for such hiatuses where the lithological changes take place. As each of the breaks occurs between cores, it is more likely that they result from changes in the position of the drill bit during the time interval between core retrievals (McManus, Burns et al., 1970).

There has been considerable discussion in the literature on the origin of metalliferous sediments associated with active ridge areas in the oceans. Boström and Peterson (1969) consider them to be of hydrothermal origin and suggest that they precipitate from mantle-derived mineralizing solutions which debouch onto the ocean floor. More recently, Corliss (1970) has proposed a mechanism to ac- count for the hydrothermal solutions in terms of the leaching of newly extruded basalt. He found that, relative to the rapidly cooled margins, the holocrystalline interiors of submarine basalt flows are depleted in $\mathrm{Mn}, \mathrm{Fe}, \mathrm{Co}$, and rare earth elements and attributes these differences to the loss of some components of the magma from the interiors of the flows. The elements concerned are thought to be concentrated in residual solutions during cooling, leading to their crystallization in accessible sites in the rock. They are subsequently mobilized by dissolution in seawater introduced along contraction joints formed in the late stages of cooling.

One alternative hypothesis for the origin of ferruginous sediments discussed by von der Borch et al. (1971) is the 
scavenging of the iron and other elements from solution by microorganisms. These authors noted the presence of possible bacterial structures in the deposits they examined. A second alternative, in areas where there is minimal biogenous and clastic sedimentation, is that the deposits result from the slow precipitation of particulate iron from seawater.

Yet another possibility, suggested by Turekian and Bertine (1970), is that some of the minor element enrichments in ocean ridge sediments may result from their deposition under anerobic conditions. Such an explanation is unlikely to apply to the sediments discussed in this work, however, for, as mentioned previously, they are well oxidized throughout.

Of the various hypotheses, hydrothermal activity can probably best explain the origin of the sediments described in this work. This may not be the only mechanism, however. Some of the sediments, such as those near the base of DSDP 162, contain little calcium carbonate, are of limited thickness, and could have been formed by the slow accumulation of particulate iron and other materials from seawater. The ferruginous spherules and grains which are abundant in these sediments are identical in appearance to those scattered in small quantities throughout most of the cores examined, indicating that such materials can be precipitated from normal seawater and are not necessarily of hydrothermal origin. However, it seems unlikely that the iron in the iron-rich chalk oozes at DSDP 162, and the other sites described in this report, could have attained these high concentrations solely as a result of slow precipitation from seawater. The rapidly accumulating carbonate phases would be expected to dilute such iron to near the low levels (1.6\%; Skornyakova, 1965) found in average pelagic carbonates. Some additional, presumably volcanic, source of iron in these sediments is therefore indicated.

\section{REFERENCES}

Bonatti, E. and Joensuu, O., 1966. Deep-sea iron deposits from the South Pacific. Science. 154, 643.

Bonatti, E., Fisher, D.E., Joensuu, O. and Rydell, H.S., 1971. Postdepositional mobility of some transition elements, phosphorous, uranium and thorium in deep sea sediments. Geochim. Cosmochim. Acta. 35, 189.
Boström, K. and Fisher, D.E., 1971. Volcanogenic U, V and Fe in Indian Ocean sediments. Trans. Am. Geophys. Union. 52, 245.

Boström, K. and Peterson, M.N.A., 1966. Precipitates from hydrothermal exhalations on the East Pacific Rise. Econ. Geol. 61, 1258.

1969. The origin of aluminum-poor ferromanganoan sediments in areas of high heat flow on the East Pacific Rise. Marine Geol. 7, 427.

Boström, K., Peterson, M.N.A., Joensuu, O. and Fisher, D.E., 1969. Aluminum poor ferromanganoan sediments on active oceanic ridges. J. Geophys. Res. 74, 3261.

Cook, H.E., 1971. Iron and manganese rich sediments overlying oceanic basalt basement, equatorial Pacific, Leg 9, DSDP. Geol. Soc. Am. Abstracts with Programs. 3 (7), 530.

Corliss, J.B., 1970. Mid-Ocean Ridge Basalts. Ph.D. thesis, Univ. California, San Diego.

Cronan, D.S., 1969. Average abundances of $\mathrm{Mn}, \mathrm{Fe}, \mathrm{Ni}, \mathrm{Co}, \mathrm{Cu}$, $\mathrm{Pb}, \mathrm{Mo}, \mathrm{V}, \mathrm{Cr}, \mathrm{Ti}$ and $\mathrm{P}$ in Pacific pelagic clays. Geochim. Cosmochim. Acta. 33, 1562.

Cronan, D.S. et al., 1972. Iron-rich basal sediments from the eastern equatorial Pacific; Leg 16, Deep Sea Drilling Project. Science. 175, 61 .

McManus, D.A., Burns, R.E. et al., 1970. Initial Reports of the Deep Sea Drilling Project, Volume V, Washington (U.S. Government Printing Office). 827 pp.

Peterson, M.N.A., Edgar, N.T. et al., 1970. Initial Reports of the Deep Sea Drilling Project, Volume II, Washington (U.S. Government Printing Office).

Shornyakova, N.S., 1965. Dispersed iron and manganese in Pacific Ocean sediments. Intern. Geol. Rev. 7, 2161.

Turekian, K.K., and Bertine, K., 1970. Deposition of molybdenum and uranium along the major ocean ridge systems. Nature. 229, 250.

Vine, F.J. and Matthews, D.H., 1963. Magnetic anomalies over oceanic ridges. Nature. 199, 947.

von der Borch, C.C. and Rex, R.W., 1970. Amorphous iron oxide precipitates in sediments cored during Leg 5, Deep Sea Drilling Project. In McManus, D.A., Burns, R.E. et al., 1970. Initial Reports of the Deep Sea Drilling Project, Volume V, Washington (U.S. Government Printing Office). 541.

von der Borch, C.C., Nesteroff, W.D. and Galehouse, J.S., 1971. Iron rich sediments cored during Leg VIII of the Deep Sea Drilling Project. In Tracey, J.I., Jr., Sutton, G.H. et al, 1971. Initial Reports of the Deep Sea Drilling Project, Volume VIII. Washington (U.S. Government Printing Office).

Zelenov, K.K., 1964. Iron and manganese in exhalations of the submarine Banu Wuhu vocano, Indonesia. Dokl. Acad. Sci. U.S.S.R. Earth Sci. Sect. 155, 91. 